ISSN 1012-227X S.Afr.j.ind.eng.

S A Tydskrif vir Bedryfsingenieurswese, Vol 6, No 1, Junie 1992, pp 1-20

\title{
CAVEATS FOR MAINTENANCE RESEARCHERS
}

\author{
D.R. Snaddon \\ Department of Business Economics \\ University of the Witwatersrand \\ P.O. Wits 2050 \\ South Africa
}

Abstract:

This paper defines maintenance and comments on information gathering for specific maintenance activities. It investigates some of the problems for those who want to research maintenance topics. Problems include slack definitions and not enough comparable information at a minimum standard of accuracy.

Opsomming: $\quad$ Hierdie artikel verskaf 'n definisie van onderhoud en lewer komentaar omtrent die insameling van inligting oor spesifieke onderhouds-aktiwiteite. Die artikel ondersoek sommige van die probleme van navorsers wat onderwerpe van onderhoud bestudeer. ' $n$ Gebrek aan die duidelike omskywing van sleutelbegrippe en 'n onvoldoende vergelykbare inligting van voldoende akkuraatheid is van hiedie probleme.

I thank two referees for their comments on the original manuscript and drawing my attention to MIL-STD-1388.

For any good in this DEO GLORIA 


\section{CAVEATS FOR MAINTENANCE RESEARCHERS}

Maintenance researchers have at least three tasks. The first is to give meaning to maintenance. The second is to classify previous work on maintenance. The third is to collect information on maintenance. These three tasks form the main sections of this paper.

\section{The Meaning of Maintenance}

The Oxford English dictionary defines maintenance as:-

"The action of keeping in effective condition, in worktng order, in repair, etc, the keeping up of.."

Maintenance derives from the Latin "manus", a hand and "teneo", to hold. This suggests a holding together of something that may otherwise break. Maintenance is narrowly defined for physical assets, plant, units or components.

One difficulty is distinguishing between capital and maintenance costs. At the macroeconomic level Feinstein says:-

"In many cases there is no sharp dividing line, so that the figures for gross investment in the year in which the dubious expenditure is incurred, may be substantially increased by taking a broad view of what constitutes major improvements, or reduced by taking a broad view of what constitutes maintenance." [16, p. 8]

Feinstein states that the dividing line between maintenance and capital cost is arbitrary. [16, p. 9] Arbitrary estimates lead to large inconsistencies in some sectors e.g. relaying and resurfacing roads. Capital is defined when assets are acquired. At this point in time capital the standards and quality are set. Maintenance of roads then improves roads to the standard when acquired. Maintenance repairs potholes when roads deterlorate. Development work which is not maintenance, macadamises gravel roads. Replacement of complete assets, e.g. roads, trucks, bulldozers, as an alternative to maintenance is not considered. Should replacement or development be viable alternatives then 
management should undertake them. This is discussed elsewhere. [50] Managers should not regard replacement or development as maintenance work.

Definitions of maintenance either point towards team work [2] or contracting behaviour [53]. Certain authors emphasize team work by defining maintenance as part of a system. Stair and Render say [45, p. 345]:-

"maintenance includes all activitles involved in keeping a system's equipment (and the entire production system) in working order."

Garrett and Silver concur [17, p. 609] but other authors have regarded maintenance as part of a specific system e.g. quality control. [8, p. 588; 19, p. 71 and 46, p. 530] Another approach is to regard maintenance as a part of the life cycle costs of plant. Maintenance is placed together with the operation. acquisition and disposal of plant in a systematic set of practices. $[47$, backcover and 7l Team work approaches give the impression that maintenance cannot be separated, in a meaningful way, from a larger system.

Other authors provide a contractual emphasis to maintenance by extricating it from operations. Chase and Acquilano say that:-

'The maintenance function may be thought of as a second production system operating in parallel wth the firm's manufacturing system" [11, p. 633].

Husband [24, p. 5] concurs with these sentiments adding:

"In many ways the maintenance department can be seen as a separate enterprise within the firm."

Maintenance includes direct repair of a broken machine as well as repair for stock and later sale. This latter strategy is the concept of exchange units where the defective unit is exchanged for a repaired unit from stock. Defective units are repaired at a later stage. This approach evolves into reconditioning or remanufacturing. To define maintenance more closely, the concept of 
remanufacturing needs to be cut out. Lund defines remanufacturing in the following terms:-

"Remanufacturing is the restoration of used products to a like-new condition. providing them with performance characteristics and durability at least as good as those of the original product". [30, p. 1]

Definitions of maintenance thus far include remanufacturing. Few would regard remanufacturing as maintenance, as such work is performed:-

"In a factory environment and the assembly processes are usually very similar to those employed in making the product originally" [30. p. 1]

Remanufacturing work is undertaken in South Africa by, amongst others manufacturers [38, pp. 3-15] forming a source of supply in the spares market. Husband [24, p. 5] has attempted to remove the type of work by clarifying maintenance as follows:-

"Its 'production' is craft orlentated and is analogous to unit or small batch manufacture"

The problems of a maintenance definition are:-

(a) Maintenance and capital costs overlap at the boundary e.g. with remanufacturing; and

(b) Maintenance is a different concept to different people.

This paper uses the following three part definition of maintenance. Maintenance:-

(a) restores parts of a system to a standard which is not superior to that when the system was acquired;

(b) is the process of fault discovery in, fault rectification of, and recommissioning of a productive system;

(c) is a subservient activity to production, restoring the capital inputs of a productive system, but remains an organizational system in its own right. 
All three parts of the definition are necessary for an activity to be classified as maintenance. [43, pp. 126-128]

To explain the first part of the definition, consider a truck which is purchased and although the truck runs hot, this is overlooked until some water pipes deteriorate. Management decide to replace the pipes which have deteriorated (maintenance work) and to install a subsidiary radiator (developmental work-not maintenance work). The subsidiary radiator failed later and was replaced (maintenance work). Where careful definition is not practised the term maintenance is misleading and cases exist where maintenance spends at least one quarter of its time on capital work. $[24, \mathrm{p} .11]$

\section{Classifying Maintenance}

\subsection{Classification}

Maintenance is mainly undertaken as a relationship between departments within firms, rather than as a market transaction. In such circumstances considering demand and supply to be independent is inappropriate le.g. see 20]. A structure based upon the economic definition of production is preferred, viz. the addition of utility, or, more prosaically, net output. This occurs when items that are broken have utility added by repair. The added utility or net output is assets leaving maintenance in a less deteriorated state than when they entered. (This approach does not exclude the real chance of complex relationships occurring between maintenance and other parties.)

Writers on repair and maintenance use different classifications. These are grouped into one of three sets, viz: breakdown, consequences, and repair. Each set has a variety of schemes and each scheme has different classes. Classes contain information on frequency or cost. Researchers may compare 
classes and draw conclusions about the relative frequency or cost. Table number 1 gives a summary of the sets and schemes of maintenance.

The first set of schemes is breakdown. Breakdown study forms the basis of maintenance action. There are three schemes in this set. The first scheme deals with location of the failure. The second scheme explains what caused the failure, for example wear. The third scheme places responsibility for the failure on a specific party, for example the manufacturer. In the "location of breakdown" scheme the object is to discover the rate at which different elements breakdown. It is popular in the literature for large plants or fleets [22, Table $8 ; 4$, p. $438 ; 34$, p. 538 ; and 41 , p. 310 l as well as component parts such as diesel engines $[9$, p. $209 ; 12$, p. $68 ; 1$, p. 19; 27, p. 208; and 36, p. 394]. In the "cause of breakdown" scheme the goal is to discover the mechanism of breakdown. Mechanisms include overstressing, scuffing, corrosion. contamination, and parts missing. [9, pp. 85-86 and 54, pp. 288-289] The material (and capital) resource is emphasized. The "responsibility for damage" scheme includes the environment, company, department, or person. Companies include manufacturers and users. Departments include operating and maintenance sections. Various institutions are interested in establishing responsibility for breakdown or damage. These include insurance companies [36, p. 6], manufacturers, legal institutions [35, section 17] and management. A reason for interest is apportioning guilt to enforce future safe procedures, or to set policies and warranties.

The second set embrace schemes analyzing the consequences of breakdown. Certain parts that break down are important, for example the engine. Other parts such as a crack in the manufacturer's logo may be trivial. Authors have 
proposed classification of the effects of the breakdown. [18, p. 86] Few investigations of the severity of breakdown have been published, [14] but the necessity for a part to function reliably varies considerably.

Table 1

Sets and Schemes of Maintenance

\begin{tabular}{|c|c|c|}
\hline & Notes & Discussion \\
\hline \multicolumn{3}{|l|}{ Breakdown } \\
\hline Location & $\begin{array}{l}\text { Where it broke. May be in } \\
\text { hierarchical form. For example: } \\
\text { fleets or factorles; units e.g. } \\
\text { trucks: complex components e.g. } \\
\text { engines; simple components e.g. } \\
\text { bearings. }\end{array}$ & $\begin{array}{l}\text { May be unique e.g. an engine or distributed } \\
\text { e.g. hydraulics. Breakdown of unit implies } \\
\text { breakdown of component, but not vice versa. }\end{array}$ \\
\hline Cause & $\begin{array}{l}\text { Mechanism of deterioration } \\
\text { e.g. wear or corrosion }\end{array}$ & Experience necessary \\
\hline Responsibility & Person or group of persons & $\begin{array}{l}\text { Varfous institutions sample differently. } \\
\text { Compare O.E.M. (warranty), insurers (claims). } \\
\text { \& users. (Called asymmetrical info.). Obtaining } \\
\text { unblased information is difficult within the } \\
\text { firm. People may be punished. }\end{array}$ \\
\hline Consequence & $\begin{array}{l}\text { Based upon location, but } \\
\text { emphasizes mission to be } \\
\text { accomplished. A crack in the } \\
\text { door handle is less serlous than } \\
\text { an equal sized crack in a piston } \\
\text { rod. }\end{array}$ & $\begin{array}{l}\text { Few can specify mission to be accomplished in } \\
\text { the detail required. }\end{array}$ \\
\hline \multicolumn{3}{|l|}{ Repair } \\
\hline Place & $\begin{array}{l}\text { For example on site by garage, } \\
\text { own crews in central } \\
\text { workshops }\end{array}$ & \\
\hline Cost & $\begin{array}{l}\text { In accounting form (rands \& } \\
\text { cents) } \\
\text { From primary documents 1.e. job } \\
\text { cards. } \\
\text { Time reported }\end{array}$ & $\begin{array}{l}\text { Inflation and technology adjustments } \\
\text { necessary. Credence of old records. } \\
\text { Fault reported may not be fault repaired. Cosis } \\
\text { may not indicate value. } \\
\text { Control of person or control of job? }\end{array}$ \\
\hline
\end{tabular}

Schemes of repair form the final set. Schemes are found according to the place [32, p. 59 and 52] or cost of repair [40, p. 216 and p. 399]. (The place of repair is often different from the location of breakdown and is hence another scheme). 
Organisations measure costs of repair at several levels of aggregation e.g. components, units, fleets. Such organisations may measure using incidents, money or time.

While reasonably pure forms of classification have been noted, some authors provide hybrid classifications which include several schemes. Examples include cross classification schemes e.g. sorting by location and cause of breakdown. [28, p. 17 and 4, p. 439] These data base approaches have the potential to provide greater insight into the fundamentals of breakdown and repair than single classification schemes.

\subsection{Discussion}

The discussion makes some general points before discussing individual schemes.

In all situations the economic rule is to gather data when expected benefits exceed expected costs.

The collection of good quality information concerning breakdown and maintenance is a formidable task subject to complications. [39, p. 902] The single aspect of wear shows the size of the task of gaining enough information. Cox says that:-

"It is impossible at present to diagnose the amount of wear in all equipment parts, and most wear must be judged from the life of the part and knowledge of job conditions." [13. p. 7-27].

Even if enough information is obtained, the choice of the classes is important as different classifications yield different information. Standardized approaches 
have been advocated. [28, Appendix 3 and 23] However published work shows a disregard for such standardization. Factors contributing to this disregard include minimal referencing to previous material and failing to define terms adequately. Situations arise when researchers are confused how to classify items. For example is an exterior light part of the bodywork or the electrical system ? Although there are some military standards which are useful in overcoming such problems e.g. MIL-STD-1388 (1), (2) and 2(B), these are seldom used commercially.

Note that any one scheme may not be able to classify all maintenance. For example maintenance diagnosis and/or action does not imply that the system has broken, is or likely to break down. [for example see 12, pp. 62-63] The quality of information on maintenance varies considerably. Some reports exist where maintenance costs are arbitrarily estimated [e.g. 15, p.1], or assumed [e.g. 37]. Researchers must exclude such studies.

\section{Researchers must gather enough comparable information that has a minimum standard of accuracy.}

This paper takes "location of breakdown" as the standard and discusses other schemes against this scheme. Some abbreviated notes are in table 1.

Some [25 and 26] argue in favour of the use of the "cause or mechanism of breakdown" scheme. Others caution against it. Rollason [38, p. 36] points out that:-

"A considerable amount of experience is necessary when investigating the cause of failures and it is advisable to examine first the working conditions. past history of the article and the stresses it has sustained before metallurglcal examination; otherwise misleading conclustons may sometimes be obtained. The classiflcation of defects and failures is extremely difficult."

In the "responsibility for breakdown" scheme a distinction is made between 
data collected extervial or internal to the company. One industry that collects external data on maintenance is insurance. [36] This data is collected only if an insurance company perceives the expected benefit as exceeding the expected cost. The cost of information gathering is significant. Insurance companies bias information on maintenance. They select breakdowns for analysis and refuse business where investigation is costly. There is a shortage of suitable, easily available insurance information. In spite of the information that should be available, insurance institutions regard much of the data as confidential or sum data to an extent to make it of little research value. Another group gathering external data is original equipment manufacturers who specialize e.g. on work undertaken during guarantee periods or for limited maintenance services. Researchers find limited information in this field. Isee 10] While groups provide partial information, each group's information is highly asymmetrical or biased. When combining all information a two fold problem arises. Firstly one cannot be sure that asymmetry is absent in the combined external information. Secondly the collection of external data may not reflect the industry or segment required.

Within an organization the costs reduce as managers learn from employees testimony. Researchers should question the validity of such testimony. Employees and managers act in an opportunistic manner. They may not give truthful information concerning responsibility. Adam and Howes point to the difficulty of obtaining truthful information from parties who perceive themselves as being singled out for punishment. Adam says that information is better gathered once repairs have been conducted and the likelihood of 
recriminations has reduced. [1, p. 20 and p. 22] The problem with waiting is that people forget, or remember in a limited way, which leads to biased interpretation.

The "cause or mechanism" and "responsibility" schemes have merit. However, contentious interpretations of terms in the former and bias in the latter make them less valid than the location of damage approach.

The second set of schemes covers the consequences of breakdown. Schemes are few and have been intimately linked with location. They are regarded as an extension rather than a separate category.

The final set of schemes analyses place or cost of repair. The analysis of the place of repair aids in evaluating the relative value of moving plant and resources and may show economising on inventory and transportation expenses. Such analysis is often peripheral to maintenance studies.

The "analysis of repair cost" has the potential to provide a basis for input costs for productivity measurement and economic decisions. However, there are at least two problems to be faced.

(a) Researchers must adjust year on year maintenance costs for comparisons. Researchers must adjust for inflation and other accounting inconsistencies.

(b) Organisations usually store accounting records over a much shorter period than the period between gaining and disposing of equipment. Even in relatively sophisticated environments there are problems in gaining access to, and the credence of, old records. [21] Again the sources of information include maintenance facilities in the open market and within organisations. In the former case similar difficulties are 
likely to arise as when researchers collect external data for breakdown analysis.

Firms usually keep internal maintenance accounts as a sub-section of the overall system. Managers require the maintenance accounting system for at least two functions. The first is to reflect costs allowed for tax purposes, the second to provide a rationale for charging. Firms gather costs in several ways, for example by contract or project, by machine, or in a maintenance account. Maintenance accounting systems are not faultless. Job cards are usually the primary documents available. The use of the job card as a source of primary information suffers from the following disadvantages:-

(a) The fault written on the job card is usually the fault reported. This may or may not be the fault repaired. On non-electrical items, the processes of diagnosis and repair may be difficult to separate, and the person performing the maintenance may not report on the actual fault, once discovered. The maintenance person may be either not suitably qualified, or suitably clean to complete such a job card.

(b) Job card's are control mechanisms over materials and labour used. Times actually spent on a particular job and that reflected on the job card may be different. The difference makes it appear that maintenance labour is fully engaged in "productive" work. The problems with primary information may cause large discrepancies in costs, especially if total costs are dependent upon labour or prime costs.

(c) The costing on the job is simply a record of costs incurred. It does not show the value of the task in a market where people are free to choose. The "analysis of repair" cost provides insight only in so far as it deals with 
economic costs and reflects the maintenance faced by the organisations. In hybrid systems many authors make no clear distinction between the various schemes of classification and categories may overlap. [3, Fig.7; and 6, p. 7, citing a B.I.M. survey] Under these circumstances the student is left in a dilemma. The researcher knows that the total number of individual breakdowns sums to the total (usually 100 per cent). This check is necessary, but not sufficient to be sure that previous authors have classified each action, correctly, once.

Where researchers exercise a choice they prefer simple schemes. They may get better estimates from expert opinion than old documents or other secondary sources.

\section{Getting Information on Maintenance}

Researchers get information on maintenance from two sources:-

Secondary market research (literature); and

Primary market research (do it yourself).

\subsection{Secondary Market Research}

There is considerable difficulty in the literature survey as:-

(a) maintenance readings are scattered with little attempt at cross referencing. Further much of the literature is contained in internal or unpublished documents. Authors often cite work unavailable to the public. 
(b) there are few articles surveying the field. Reviewers limit themselves to the operations research or management science literature. These reviews are not applicable in most instances. [40, Appendix 4.1]

\subsection{Primary market research}

The area chosen is not easy to research. Problems include people who find maintenance not interesting and the lack of valuable information.

Maintenance is non interesting in that there are people, exposed to the area that bypass it completely. For example in conferences where people should show interest, people ignore the area. [48] Others cite maintenance as being the Cinderella of industry [e.g. 31, p. 61, para 8].

The argument for the lack of valuable information may be split into the area of theoretical knowledge and field study. Theoretical models confirmed by field studies produce precise knowledge with better predictive value.

The theoretical knowledge of maintenance suffers from a lack of laws or confirmed hypotheses. One problem is generalisation from specific cases brought about by testing over a narrow range of operating conditions. These generalisations add to the confusion [for comments on wear see 29, p. 1 and for breakdown see 5, p. 46]. However some, who are perceptive enough, query partly true statements. In the reliability area Bennet and Jenny [4] are wise enough not to simply accept the conventional wisdom of bathtub theory. They say:-

"...Industrial machines, being for a large part mechanical and hydraulic in nature, have not yet received the same degree of attention and very little published material therefore relates to the reliability of such equipment". (pp. 433-434) 
Since they made this statement there is evidence that Bennet and Jenny are correct and conventional wisdom is wrong! [44, p.142]

Researchers have to undertake large field studies as little theory is available. To get a wide variety of conditions costly surveys are necessary. These may be fruitful if companies record such information "adequately". Investigations by the British Institute of Management showed that only sixty per cent of companies with a transport function kept separate vehicle operating records. [51. pp 201]

One of the reasons for the lack of information is the work required. For the single decision on replacement:-

"The largest single actlvity in carrying out a study of vehicle replacement is the collection and analysis of repairs and maintenance costs." [39. p. 902]

This is compounded when data is not available in a readily accessible form and is incomplete.

In collecting field data good quality (hence high cost) is important. Other problems remain.

(a) Organisational records differentiate little between elements making up the maintenance activities. Smith et al report average errors, in manhours per maintenance task, of over two hours. [42, p. 276]

(b) Commercial or military secrecy may be a problem. [33]

(c) Organisations do not collect data in a form suitable for maintenance. In developing countries the situation is worse than in developed countries. [See 49, especially p. 21] Researchers could expect that SA information is inferior to the standard of developed countries such as Britain cited above.

(d) Some researchers display excessive tenacity or bias (compare 
Slabbert and Robinson [41] and Ball's [22, p.7] costs with Snaddon's [40. p.40.J costs)

The conclusion must be that maintenance activity still receives scant attention.

\section{Conclusion}

Research in maintenance is full of dangers. These include weak definitions and not enough comparable information at a minimum standard of accuracy. Researchers see weak definitions in the classification of maintenance. Authors classify maintenance into breakdown or repair sets. The breakdown set includes location, cause and responsibility schemes of maintenance. The location scherne looks at the position of damage. The cause scheme studies the mechanisms of damage which include wear and corrosion. The responsibility scheme looks for the person liable for the damage. The "cause" and "responsibility" schemes have merit. However, contentious interpretations of terms in the former and btas in the latter make them less valid than the "location" of damage approach. The repair set analyses restoration costs. This set provides insight only in so far as it deals with economic costs and reflects the maintenance faced by the organisations.

Consider the problem of not enough comparable information at a minimum standard of accuracy. Maintenance readings are scattered with little attempt at cross referencing. Authors cite much literature contained in internal or unpublished documents. Such literature is unavailable for scrutiny. There are no applicable surveys of the field. The area is not easy to research because some regard it not to be interesting and there is a lack of valuable information. 


\section{$\underline{\text { References }}$}

1. Adarn. H.D. Preventive Maintenance from Breakdown Experience. Diesel Engineers and Users Association, London. July 1954, no. S236, pp. 1-45.

2. Alchian. A. and Demsetz, H. Production, Information Costs and Economic Organisation. American Economic Review, Dec. 1972, vol. 62, no. 5, pp. 777-795.

3. Bacher, G.R. The Management of Preventive Maintenance. Conference: Opencast 82, held on 21 Sept. 1982 at the State Pavilion, Milner Park. Johannesburg by the South African Institution of Mechantcal Engineers. Paper B6, unnumbered pages.

4. Bennett. D.J. and Jenny, B.W. Reliabllity: its Implications in Production Systems Design. Omega, 1980 , vol. 8, no. 4 , pp. 433-440.

5. Blackman. W.D.H. Terotechnology in REME. Proceedings of the first conference on terotechnology held in London. 3-4 May 1972. Published as Terotechology in Iron- and Stelworks. London: The Iron and Steel Institute.

6. Bolton, L.A. Design Audits and Tribology, Tribology, vol. 13, no. 1. Feb. 1980. pp. 7-10.

7. British Standards 3811:1974. Glossary of maintenance terms in Terotechnology. British Standards Institution, 1974.

8. Buffa, E.S. Modern Production Management. 5th ed.. New York: Wiley/Hamilton, 1977.

9. Carter, A.D.S. Achieving Quallty and Reliability. Proceedings of the Institution of Mechanical Engineers, 1974, vol. 188, no. 13. pp. 201-213.

10. Charissis, N., Hauk, W.A.J., Middleton, J.L. and Vangelatos, P. An Investigation into the Quality System at (name of company) Products, 10 th November 1978. Unpublished Research Project. School of Mechanical Engineering. University of the Witwatersrand, Johannesburg.

11. Chase, R.B. and Acquilano. N.J. Production and Operations Management- a life cvcle approach. 3rd ed., Homewood: R.D. Irwin. 1981.

12. Chew, N.B. Long Distance Highway Transportation, Proceedings of the Institution of Mechanical Engineers. Automobile Division. 1968-69, vol. 183, part 2A. no. 2. pp. 53-68.

13. Cox. E.A. Economics. In: Havers J.A. and Stubbs F.W., eds., Handbook of Heavy Construction. 2nd ed., New York: McGraw-Hill, 1971. ch. 7.

14. Denicoff. M., Haber, S.E. and Varley, T.C. Military Essentiality of Naval Aviation Spare 
Parts. Management Science, 1967, vol. 13, pp. B439-B453.

15. Department of Agriculture. Guide to Machinery Costs. May 1983, Dept. of Agriculture. Natal Reglon, Pretoria ISBN 0-86815-083-5.

16. Feinstein, C.M. Domestlc Capital Formation in the U.K.: 1920-1938. In: Studies in the National Income and Expenditure of the U.K. Cambridge: University Press, 1965, vol. 4.

17. Garrett. L.J. and Silver. M. Production Management Analysis. 2nd ed., New York: Harcourt Brace Jovanoich, 1973.

18. Green, A.E. Reliability Assessment of Industrial Plant Systems. In: Buschman C.H.. ed.. Loss Prevention and Safety Promotion in the Process Industries, Proceedings of the Ist International Loss Prevention Symposium held at the Hague on 28-30 Mav 1974. Amsterdam: Elsevier, 1974, pp. 81-99.

19. Harry, M.J.S. Production Management. London: Hutchinson. 1972.

20. Hillebrandt, P.M. Economic Theory and the Construction Industry. London: Macmillan, 1974.

21. Horowitz, S. and Shishko, R. A Model for Evaluating VSTOL Versus CTOL Combat Aircraft Systems. Management Science, Dec. 1971, vol. 18, no. 4, Part 1, pp. B-186 to B-199.

22. Howat. D.D. and Enright, D.P. An Analysis of the Replies to a Questionnaire on Materials of Construction for Ore Hoppers. Randburg: National Institute for Metallurgy. Report no.1908, 16th Sep. 1977, I.S.B.N. O 86999395 X.

23. Hunt, Leuchars and Hepburn. Preventive Maintenance. Internal Documentation, undated.

24. Husband, T.M. Maintenance Management and Terotechnology. Aldershot: Gower. 1982.

25. Kldman, E.E., Don't just replace-analyse. Construction S.A. Dec. 1973, Supplement- Plant htre in construction, pp. 5-16.

26. Lanchaster, J.F. What Causes Equipment to Fall? Hydrocarbon Processing. Jan. 1975, vol. 54, no.1, pp. 74-76.

27. Little. L.F. Some Problems in the Design of Crawler Tractors. Proceedings of the Institution of Mechanical Engineers. Automobile Division, 1959-1960, vol. 7. pp. 193-214.

28. Lorenzato, A. and Mackinnon, D. Avis Truck maintenance. Unpublished Research Report. School of Mechanical Engineering. University of the Witwatersrand, Johannesburg. June 1982. 
29. Ludema, K.C. Selecting Materlal for Wear Resistance. In: Rhee S.K., Ruff A.W. and Ludema K.C. Wear of Materiais, 1981. Proceedings of an International Conference on the Wear of Materials held in San Francisco, Mar. 30-1 Apr. 1981. New York: The American Society of Mechanical Engineers, pp. 1-6.

30. Lund, R.T. Remanufacturing: The Experience of the United States and Implications for Developing Countries. Washington, D.C.: The World Bank, 1984. World Bank Technical Paper no. 31, UNDP Project Management Report 2, pp. 1-103.

31. MacDonald, A. Organisation and Planning of Matntenance with Particular Reference to Cost Reduction. Conference on Terotechnology in the Process Industries held at Durham. England, 27-28 March 1973. London: Institution of Mechanical Engineers, 1973, no. C101/73. pp. 61-67.

32. Matertals Handling. Analysis Isolates the Vital Targets. Business Press International Ltd.. Sept. 1983. no 309.

33. McEwen E.G. Discussion to Little (1959-1960, p203) op. cit.

34. McKay, Maj. Gen. A.M. A Whole-Life Approach to the Engineering Support of Equipment. Proceedings of the Institution of Mechanical Engineers, 1975, Vol. 189, No. 5, pp. 533-540.

35. M.O.S.A. Machinery and Occupational Safety Act, Act no. 6 of 1983.

36. Munich Re, Machinery Loss Prevention. Tr. P. Cahn-Speyer. Wurtburg: Universitatsdruckerel, Munich Reinsurance Company, April 1978.

37. Nel, T.W. and Groenewald. J.A. Performance, Fuel Consumption and Repair Costs of Tractors in the North-Westem Free State. Pretoria: Department of Agricultural Economics and Marketing, c. 1978.

38. Plant. Plant and back up- the Barlows way. Feb. 1982, vol. 6, no. 1, pp. 3-15.

39. Russell. J.C. Vehicle Replacement: a Case Study in Adapting a Standard Approach for a Large Organisation. Journal of the Operational Research Society. 1982, vol. 33. pp. 899-911.

40. Scott, G.A. and Bellamy, J.K. Application of C.I. Engines to Excavators and Cranes. Diesel Engineers and Users Association, London, Mar. 1962, no. S281, pp. 1-19.

41. Sherwin, D.J. and Lees, F.P. An Investigation to the Application of Fallure Data Analysis to Decision-making in Maintenance of Process Plant. Proceedings of the Institution of 
Mechanical Engineers, Englneering Manufacturing Industries Divtsion, 1980, vol. 194, pp. 301-319 and S57-S61.

42. Smith, R.L., Westland, R.A. and Crawford, B.M. The Status of Maintainability Models: a Critical Review. Human Factors, 1970, vol. 12. no. 3, pp. 271-283.

43. Snaddon, D.R. The Cost of Maintenance to the Republic of South Africa. The South African Mechantcal Engineer. Aprll 1980, vol. 30, no. 4. pp. 126-131.

44. Snaddon D.R. Breakdown Theorles and Complex Units-a Crittque. Omega. Vol. 16. No. 2. pp. 135-143, 1988.

45. Stair, R.M. and Render, B. Production and Operations Management. Boston: Allyn and Bacon, 1980.

46. Starr, M.K. Operations Management. Englewood Cliffs: Prentice-Hall, 1978.

47. Terotechnology in Iron- and Steelworks. Proceedings of the First Conference on Terotechnology held in London, 3-4 May 1972. London: The Iron and Steel Institute. Printed Bradford: Country Press.

48. Transportation in SA: Conference held between the 23rd and 25th of April 1979.

49. UNIDO, Maintenance and repair in developing countries. Report of the symposium held at Duisberg, Fed. Rep. of Germany, 10th-17th Nov. 1970. United Nations Industrial Development Organisation. Vienna, NY, 1971, pp 1-90.

50. Vorster, M.C. A Systems Approach to the Management of Civil Engineering Construction Equipment. Unpublished PhD thesis, University of Stellenbosch. June 1980.

51. Westwood, J.B. An Empirical Excursion into the Quicksand of Vehicle Replacement. Omega, 1981, vol. 9. no. 2, pp. 195-202.

52. Whyte, W.H. Discussion to PIrie Fluid Power in the Construction Industry: the Contractor's Point of View. Proc. of the Inst. of Mech. Engs.. Fluid Plant and Machinery Group. 1972 , Vol. 186 , No. 58 . pp. $683-691$ at p. D240

53. Willamson, O.E. Transaction-cost economics: the governance of contractual relations. The Joumal of Law and Economics, 1979, pp. 233-261.

54. Wilson, RW. The Diagnosis of Engtneering Fallures. The South African Mechanical Engineer, Nov. 1972, vol. 22, no. 11, pp. 286-303. 